\title{
Cimetidine in the prevention of gastric ulcer relapse
}

\author{
R. J. MACHELL \\ M.A., M.B., M.R.C.P. \\ M. J. G. FARTHING* \\ B.Sc., M.B., M.R.C.P.
}

\author{
P. J. Ciclitira \\ M.B., M.R.C.P.
}

\author{
A. P. Dick \\ M.A., M.D., F.R.C.P.
}

\author{
J. O. HUNTER \\ M.A., M.D., M.R.C.P.
}

Department of Medical Gastroenterology, Addenbrooke's Hospital, Cambridge

\begin{abstract}
Summary
Twenty-five patients with healed gastric ulcers completed an 11-month double-blind controlled trial comparing cimetidine $1 \mathrm{~g}$ daily with placebo in the prevention of ulcer relapse. Ulcers recurred in 14 patients, 12 on placebo, 2 on cimetidine. In 11 patients, 9 on cimetidine, 2 on placebo, the ulcers remained healed at the end of the trial $(P<0.002)$.

Cimetidine $1 \mathrm{~g}$ daily significantly reduces the relapse rate in gastric ulceration.
\end{abstract}

\section{Introduction}

It has been established that the histamine $\mathrm{H}_{2}$ receptor antagonist, cimetidine, promotes healing of duodenal ulcers (Bodemar and Walan, 1976; Blackwood et al., 1976; Haggie, Fumont and Wyllie, 1976). The role of cimetidine in the treatment of gastric ulceration is less clear, although healing does occur in 60 to $80 \%$ of cases with a $4-$ or 6-week course of treatment (Ciclitira et al., 1977; Multicentre Trial, 1977; Frost et al., 1977; Dyck et al., 1978).

The high incidence of subsequent recurrence, however, remains a major problem in the long-term medical management of both gastric and duodenal ulcers (Leading Article, 1977). Recent studies (Gray et al., 1978; Blackwood, Maudgal and Northfield, 1978) have shown that maintenance cimetidine therapy is effective in preventing duodenal ulcer relapse in the majority of cases.

The efficacy of cimetidine in the prevention of gastric ulcer relapse has been studied in a doubleblind controlled trial.

\footnotetext{
* Present address: Department of Gastroenterology, St Bartholomew's Hospital, London.
}

\section{Patients and methods}

Patients with endoscopically-proved benign gastric ulcers were initially treated with cimetidine or placebo in a 4-week trial. The protocol of this trial has previously been published (Ciclitira et al., 1977). When endoscopic confirmation of complete healing had been obtained, either after the initial 4 weeks' treatment or, in some instances, following a further 4-week course of cimetidine the patients were entered, within 4 days of endoscopy, into the maintenance trial which continued for 11 months. All patients gave their informed consent.

The patients were randomly allocated into 2 groups, one receiving cimetidine $200 \mathrm{mg} 3$ times daily, with $400 \mathrm{mg}$ at night, and the other identical placebo tablets containing lactose.

Both groups were supplied with unmarked antacid tablets (Rennies, Nicholas Laboratories) with instructions to take them as required.

Follow-up was at monthly intervals, when symptoms, antacid consumption, the number of trial tablets taken, and the occurrence of any adverse reactions were recorded. Blood samples were taken before entry to the trial and at each follow-up visit for a full blood count, plasma electrolytes, urea and creatine, uric acid and liver function tests. Endoscopy was repeated at 5 and 11 months when the trial ended, or at any stage in the event of symptomatic recurrence. Patients were withdrawn from the trial if ulcer relapse was confirmed.

Fisher's exact probability test was used to compare the frequency of ulcer relapse and the $\chi^{2}$ test to assess the occurrence of pain in the 2 groups.

\section{Results}

Thirty-one patients entered the trial and 25 
TABLE 1. Comparison of cimetidine and placebo groups

\begin{tabular}{ccccccc}
\hline No & Treatment & Male & Female & Smokers & Age (years) & $\begin{array}{c}\text { Length of ulcer } \\
\text { history (years) } \\
\text { mean }( \pm s . d .)\end{array}$ \\
\hline 11 & Cimetidine & 6 & 5 & 6 & $59 \cdot 1 \pm 9 \cdot 4$ & $7 \cdot 1(10 \cdot 1)$ \\
14 & Placebo & 8 & 6 & 8 & $59 \cdot 5 \pm 11 \cdot 0$ & $7 \cdot 9(8 \cdot 1)$ \\
\hline
\end{tabular}

completed the study. Five patients defaulted from follow-up all within a few weeks. One 61-year-old man, a known hypertensive, receiving cimetidine died from a cerebro-vascular accident. No sideeffects were observed and there were no significant alterations in the haematological and biochemical parameters assessed.

Of the 25 patients who completed the study, 24 originally had lesser curve ulcers and one a prepyloric ulcer. The 2 treatment groups were comparable with regard to age, sex, smoking habits and duration of ulcer disease (Table 1). Eleven patients received cimetidine, 14 placebo. Gastric ulcers recurred during the trial period in 14 patients 12 on placebo, 2 on cimetidine. In 11 patients, 9 on cimetidine, 2 on placebo, the ulcers remained healed at the end of the 11-month trial period $(P<0.002)$.

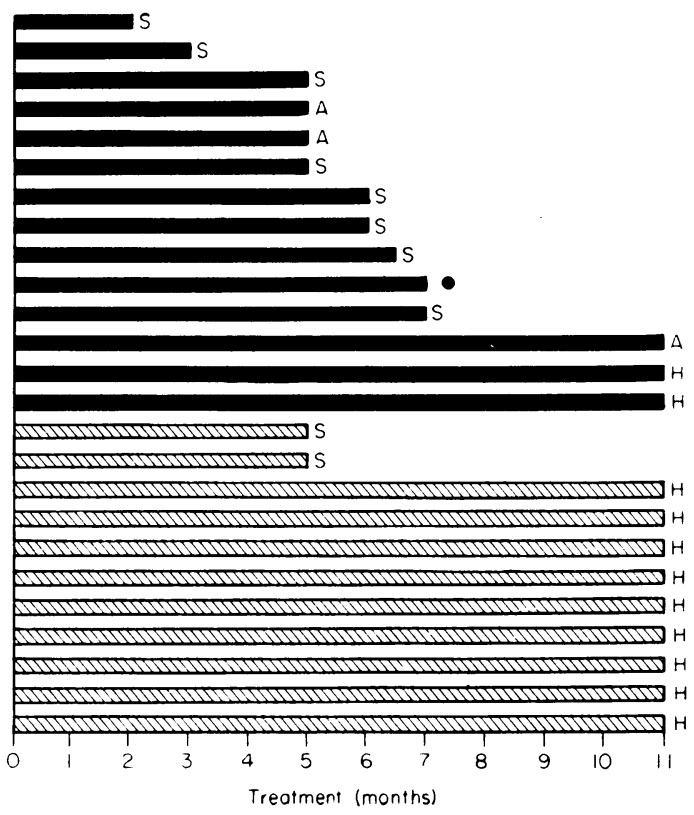

Fig. 1. Progress of patients in the trial.

- Placebo group (14 patients); $\mathbb{N}$ cimetidine group (11 patients).

S Recurrent symptomatic gastric ulcer.

A Recurrent asymptomatic gastric ulcer.

H Remains healed after 11 months.

- Recurrent symptomatic gastric and duodenal ulcers.
The timing of relapse is shown in Fig. 1. The $\frac{\mathbb{D}}{\mathrm{D}}$ mean time to relapse in the placebo group was 5.75 months. One patient on placebo who relapsed ${ }^{\text {कs }}$ at 7 months had a duodenal ulcer as well as a re- $\overrightarrow{0}$ current gastric ulcer.

Return tablet counts demonstrated that both $\vec{\omega}$ patients on cimetidine who relapsed had omitted to $\bar{D}$ take the correct number of tablets.

Nine out of 11 patients on cimetidine remained free from ulcer pain during the trial as compared to 5 out of 14 patients on placebo $(P<0 \cdot 05)$. Cimetidine- $+\vec{A}$ treated patients consumed less antacid tablets $\dot{\omega}$ throughout the trial than those treated with placebo, $\stackrel{\oplus}{\omega}$ although the difference was not significant.

Discussion
This study, over 11 months, demonstrates that $\frac{c}{\bar{D}}$ cimetidine $1 \mathrm{~g}$ daily significantly reduces the in- $\overrightarrow{0}$ cidence of gastric ulcer relapse.

Twenty-two of the 25 patients who completed the $\frac{0}{6}$ study had originally healed their gastric ulcer wi cimetidine before entry into this trial. Of the patients whose ulcers originally healed on placebo, 2 remained healed on maintenance cimetidine and one patient relapsed on cimetidine. The risk of $\stackrel{\mathbb{Q}}{\complement}$ relapse appeared unrelated to whether the original $\overrightarrow{\vec{A}}$ ulcer had healed on cimetidine or placebo tablets.

In this maintenance trial the high rate of ulcer recurrence in the placebo-treated group (12 of 14함 patients) suggests that the majority of patients will have recurrent gastric ulcers within 6 months of 3 . the initial healing. This is similar to the experience $\frac{0}{\sigma}$ with cimetidine in duodenal ulceration (Haggie et al., 1976; Blackwood et al., 1978).

This study included a single patient with a prepyloric ulcer, which remained healed on cimetidine. 을 As ulcers at this site are often, like duodenal ulcers, associated with increased gastric acid secretion, it can be argued that cimetidine might be expected to be more effective in preventing relapse of this type or of ulcer. If this patient is excluded from the analysis $N$ the results remain highly significant $(P=0.002)$.

In the United Kingdom, gastric ulceration is principally a disease of the elderly and the morbidity and mortality associated with complications such $\underset{\mathbb{D}}{\stackrel{2}{ }}$ as haemorrhage is high. In many such patients, ? particularly those with intercurrent disease, ulcer 0 surgery is also associated with significant risk (Allan and Dykes, 1976). 
Maintenance treatment with cimetidine offers a safe and effective alternative to surgery in the prevention of gastric ulcer relapse and would appear to have an important role in this disease. There is, however, no evidence that prolonged treatment will alter the ulcer diathesis.

It remains to be seen whether a lower dose of cimetidine will also prove effective in preventing gastric ulcer recurrence.

\section{Acknowledgments}

We wish to thank Smith, Kline and French Laboratories, Welwyn Garden City, for supplies of cimetidine, $\mathrm{Mr}$ R. Hanka, Lecturer in Statistics, University of Cambridge, for statistical advice, Sister P. M. Mountford and staff for invaluable assistance with endoscopy and Mrs S. R. Hanzl for secretarial assistance.

P.J.C. holds the Drummond Research Fellowship.

\section{References}

Allan, R. \& Dykes, P. (1976) A study of the factors influencing mortality rates from gastro-intestinal haemorrhage. Quarterly Journal of Medicine, 180, 533.

Blackwood, W.S., Maudgal, D.P., Pickard, R.G., LawRENCE, D. \& Northfield, T.C. (1976) Cimetidine in duodenal ulcer. Lancet, ii, 174.

Blackwood, W.S., Maudgal, D.P. \& Northfield, T.C. (1978) Prevention by bedtime cimetidine of duodenal ulcer relapse. Lancet, i, 626.
Bodemar, G. \& Walan, A. (1976) Cimetidine in the treatment of active duodenal and pre-pyloric ulcers. Lancet, ii, 161.

Ciclitira, P.J., Machell, R.J., Farthing, M.J.G., Dick, A.P. \& Hunter, J.O. (1977) A controlled trial of cimetidine in the treatment of gastric ulcer. In: Cimetidine: Proceedings of the Second International Symposium on Histamine $\mathrm{H}_{2}$-Receptor Antagonists (Ed. by Burland, W.L. \& Simkins, M.A.), p. 282. Excerpta Medica, Amsterdam.

Dyck, W.P., Belsito, A., Fleshler, B., Liebermann, T. R., Dickinson, P.B. \& Wood, J.M. (1978) Cimetidine and placebo in the treatment of benign gastric ulcer, Gastroenterology, 74, 410.

Frost, F., Rahbex, I., Rune. S.J., Birger Jensen, K., Gudmand-Hoyer, E., KraG, E., RASK-MAdSEN, J., WulfF, H.R., Garbol, J., Gotlieb Jensen, K., Hojlund, M. \& Nissen, V.R. (1977) Cimetidine in patients with gastric ulcer: a multicentre trial. British Medical Journal, 3, 795.

Gray, G.R., Smith, I.S., Mackenzie, I. \& Gillespie, G. (1978) Long term cimetidine in the management of severe duodenal ulcer, dyspepsia. Gastroenterology, 74, 397.

Haggie, S.J., Fumont, D.C. \& Wyllie, J.H. (1976) Treatment of duodenal ulcer with cimetidine. Lancet, $\mathbf{i}, 983$.

Leading ARticle (1977) Preventing recurrence of ulcers. British Medical Journal, 2, 1440.

Multicentre Trial (1977) Treatment of gastric ulcer by cimetidine. In: Cimetidine: Proceedings of the Second International Symposium on Histamine $\mathrm{H}_{2}$-Receptor Antagonists (Ed. by Burland, W.L. \& Simkins, M.A.), p. 287. Excerpta Medica, Amsterdam. 